\title{
DETECTION OF CRYPTOSPORIDIUM OOCYSTS IN OVINE AND CAPRINE RAW MILK IN RELATION TO REARING MANAGEMENT
}

\author{
M.H. HASAN ${ }^{1}$; A.F. AL-TAEE ${ }^{1}$; A.K. AL-HUBAETY ${ }^{2}$ and A.J. ALANI ${ }^{1}$ \\ ${ }^{1}$ Department of Microbiology, College of Veterinary Medicine, University of Mosul, Iraq \\ ${ }^{2}$ Department of Animal Resoeses, College of Agriculture, University of Mosul, Iraq
}

Received: 22 November 2017; Accepted: 28 December 2017

\begin{abstract}
During the present study an investigation was made for the assessment of the availability of oocysts of Cryptosporidium spp. in 100 samples of raw milk of sheep and goats reared in various places (Baasheqa, Hamdania and Tilkaif) in Ninevah, Iraq. Results revealed that the incidence rate of Cryptosporidium spp. oocysts in raw ovine and caprine milk samples were $32 \%$ and $46 \%$, respectively. The type of rearing management has an effect on the incidence of oocysts in raw milk of these animals. Results showed that the contamination with Cryptosporidium oocysts in mixed (sheep and goats) rearing management of there animals was higher $(\mathrm{p}<0.05)$ than separate rearing management.
\end{abstract}

Key words: Cryptosporidium, oocysts, raw milk, ovine, caprine.

\section{INTRODUCTION}

Cryptosporidium spp. are tiny protozoon parasite capable of infecting the digestive and respiratory tracts of human and most other animals (Naciri et al., 1999; Urquhart et al., 2003). Among these species Cryptosporidium parvam is the major zoonotic species causing neonatal diarrhea in farm animals. Shedding of oocysts of Cryptosporidium in the faeces of infected animals can be considered as an important contributor to environmental contamination world wide (Smith et al., 1995). Haider et al. (2014) described that the oocyst is critical stage and mainly responsible for causing infection with typical gastrointestinal manifestation in human, and symptoms are watery diarrhea, nausea, vomiting, abdominal cramp and fever for immunocompromised persons. In Iraq (Rasheed, 1997) studied cryptosporidiosis in goat kids found a prevalence of (5.84 \%) in Baghdad region, while (Abdulla, 2005) reported the prevalence rate was $(26.6 \%)$ in sheep in different localities of Ninevah province. (Casemore $e t$ al., 1986, Casemore, 1990 a) mentioned that there is a strong association between occurrence of cryptosporidiosis with the consumption of unpasteurized raw milk in addition to other animal products in the rural population in England and similar reports have been mentioned by (Mann et al., 1986, Smith, 1993) else where in the world.

Corresponding author: Dr. M.H. HASAN

E-mail address: manalhimmadi69@yahoo.com

Present address: Department of Microbiology, College of

Veterinary Medicine, University of Mosul, Iraq
(Harp et al., 1996) reported that transmission of Cryptosporidium parvum oocysts came from contaminated water and unpasteurized raw milk. Many authors showed presence of viable oocysts in the raw milk, raw meat and other raw foods (Casemore 1990 b; Laberge et al., 1996; Hassan et al., 2002, Smith and Nichole, 2009).

\section{MATERIALS AND METHODS}

One hundred samples of raw milk from sheep and goats were collected from different locatities in Ninevah governorate (Baasheqa, Hamdania and Tilkaif). These animals are of local Iraqi breeds their ages ranged between (1-3 years). These sheep and goats were reared under mixed rearing conditions, and another groups where kept separates from each other, the milk samples were kept in sterilized containers and transported directly under hygienic conditions to the laboratory of Parasitology in the College of Veterinary Medicine (Mosul) for laboratory investigations for detection of oocysts of Cryptosporidium spp., concentration technique was performed to these samples for the collection of oocysts of Cryptosporidium according to the method mentioned by (Dubey et al., 1980; Deng and Cliver, 1999). Smears were made from the sediments and stained by the conventional method of modified acid fast stain (Forbes et al., 2007) the data were analysed by chi-sequar according to (Katz, 2006). 


\section{RESULTS}

The results of this study showed that the incidence rate of Cryptosporidium spp. oocysts in ovine raw milk was (32\%) (Figure 1 and Table 1) while that in caprine milk was (46\%) (Table 2). Results also revealed the incidence rate of Cryptosporidium oocysts in raw milk varied with different location in Ninevah province. Raw milk of ovine contain oocysts higher in Baasheqa (39.1\%) and lower (23.1\%) in Hamdania (Tabel 1). Cryptosporidium spp. oocysts in caprine raw milk was higher in Hamdania $(68.8 \%)$ (Table 2).
Variation in incidence rate of Cryptosporidium spp. oocysts were presence according to type of rearing management of sheep and goats. Results indicated that the incidence rate of oocysts of Cryptosporidium was higher $(51.9 \%)$ significantly $(\mathrm{p}<0.05)$ in mixed rearing management of animals. While, incidence rate of oocysts were $(19.2 \%),(31.8 \%)$ in sheep and goats respectively. However incidence rate of oocysts in sheep was significantly higher $(\mathrm{p}<0.05)$ compared to mixed rearing management (Table 3).

Figure (1): Cryptosporidium spp. oocysts recovered from raw milk samples stained with acid fast stain (100 X).

Table 1: Incidence rate of Cryptosporidium spp. oocysts in ovine raw milk: Ninevah.

\begin{tabular}{cccc}
\hline Areas of study & No. of samples examined & No. of positive samples & $\begin{array}{c}\text { Incidence rate of } \\
\text { Cryptosporidium spp. \% }\end{array}$ \\
\hline Baasheqa & 23 & 9 & 39.1 \\
\hline Hamdania & 13 & 3 & 23.1 \\
\hline Tilkaif & 14 & 4 & 28.6 \\
\hline Total & 50 & 16 & $32 \%$ \\
\hline
\end{tabular}

Table 2: Incidence rate of Cryptosporidium spp. oocysts in caprine raw milk in the areas of this study in Ninevah.

\begin{tabular}{cccc}
\hline Areas of study & No. of samples examined & No. of positive samples & $\begin{array}{c}\text { Incidence rate of } \\
\text { Cryptosporidium spp. \% }\end{array}$ \\
\hline Baasheqa & 21 & 17 & 33.3 \\
\hline Hamdania & 16 & ${ }^{*} 11$ & 68.8 \\
\hline Tilkaif & 13 & 5 & 38.5 \\
\hline Total & 50 & 23 & $46 \%$ \\
\hline
\end{tabular}

\footnotetext{
* Significantly different from Baasheqa group $\mathrm{p}<0.05$
} 
Table 3: Incidence rate of Cryptosporidium spp. oocysts in ovine and caprine raw milk according to rearing management.

\begin{tabular}{cccc}
\hline Type of rearing management & $\begin{array}{c}\text { No. of samples } \\
\text { examined }\end{array}$ & $\begin{array}{c}\text { No. of positive } \\
\text { samples }\end{array}$ & $\begin{array}{c}\text { Incidence rate of ryptosporidium } \\
\text { spp. oocysts \% }\end{array}$ \\
\hline Sheep & 26 & 5 & 19.2 \\
\hline Goats & 22 & 7 & 31.8 \\
\hline Mixed (sheep\& goats ) & 52 & $27^{*}$ & 51.9 \\
\hline Total & 100 & 39 & $39 \%$ \\
\hline
\end{tabular}

* Significantly different from the sheep group $\mathrm{p}<0.05$.

\section{DISCUSSION}

The results of the present study showed that the incidence rate of Cryptosporidium oocysts in ovine raw milk was $32.0 \%$ while that in caprine milk was $46.0 \%$. This comes from the shedding of oocysts in the faeces of these animals leading to contamination of udder and subsequently of the milk with oocysts of Cryptosporidium (Deng and Cliver 1999, Duffy and Moriarty 2003). The high incidence rate of Cryptosporidium oocysts in raw milk of goats is due to the special behavioural pattern of the goat which includes the agility, more curious and is comparatively more active than sheep (Kligour and Dalton 1984). Further, udder and teats of milking goats are larger in size than that of ewes therefore the udder of goats become more exposed for contamination than ewes (Dyce et al., 2010).

The results of this study also revealed that the incidence of Cryptosporidium oocysts in raw milk varied with different locations in Ninevah, it was found that ovine raw milk was higher in oocysts in Baashiqa (39.1\%) and lower in Hamdania (23.1\%). While Cryptosporidium oocysts in caprine raw milk was higher in Hamdania (68.8\%). These variation are attributable to difference in animal management, similar things were mentioned by others. Further more (Norhamizah et al., 2011) mentioned that the management of the farm which was poor in nutrition and cleanliness led to Cryptosporidium spp. infection in the cattle compounded by stress factors. (Mohammed et al., 1999) also mentioned the preweaning factors such as use of ventilation in calf rearing areas, daily addition bedding, feeding of milk replacer and other managemented factors significantly decreased the risk of an infection with Cryptosporidium parvum.

The results reported here also showed that the incidence rate of oocysts of Cryptosporidium was $51.9 \%$ which is higher significantly $(p<0.05)$ in mixed rearing management of animals. While those animals reared separately had incidence rate $19.2 \%$, $31.8 \%$ in ovine and caprine raw milk respectively. The variation in these rates were due to the characteristic of oocysts of C.parvum which lacks host specificity. Further more oocysts of this parasites are capable of infecting another hosts immediately following this shedding. This contribute to increase the chances of transmission of the parasite between different animals (Xiao et al., 2004, Urquhart et al., 2003).

Previous studies in Ninevah, however reported that infection rates of Cryptosporidium in sheep and goats were $(35.1 \%, 26.4 \%)$ respectively (Bakir, 2005). Mosa (2016) found that incidence of cryptosporidium spp.in sheep and goat milk samples based on microscopic examination was $31.43 \%$ and $20 \%$, respectively. The availability of this level of oocysts, however, contribute to contamination of the environment further more this parasites is known to be zoonotic and its transmission occurs through oral fecal rout between hosts (Taylor et al., 2007).

These findings suggest that sufficient care should be given to the raw milk before its consumption by the people. Further studies should be done to throw more light on the role of small ruminants in disseminating infection with cryptosporidiosis to humanbeing.

\section{REFERENCES}

Abdulla, I.A. (2005): Prevalence of Cryptosporidium in sheep in different localities of Ninevah province, Iraq. Rafi. J. Sci. 16(7): 93-101.

Bakir, M.H.H. (2005): The study of epidemiology, experimental, immumity and transmission for Cryptosporidium in Nineveh Governorate Ph.D. Thesis, College of Veterinary Medicine, University of Mousl - Iraq.

Casemore, D.P. (1990a): Epidemiological aspects of human cryptosporidiosis. Epidemiol. Infect., 104, 1-28.

Casemore, D.P. (1990b): Foodborne illness: food borne protozoal infection. Lancet 336, 14271432.

Casemore, D.P.; Jessop, E.G.; Douce, D. and Jackson, F.B. (1986): Cryptosporidium plus Compylobacter: an outbreak in semi-rural population. J. Hyg. 96, 95-105. 
Haider, S.S.; Sherwani, S.K.; Khan, R.U.; Ziaulla; Shah, M. and Manir, S. (2014): Cryptosporidium; a diarrhea causing parasite. Can. J. App. Sci., 1(4): 18-25.

Harp, J.A.; Fayer, R.; Pesch, B.A. and Jackson, G.J. (1996): Effect of pasteurization on infectivity of Cryptosporidium parvum oocysts in Water and milk. Appl. Environ. Microbial., 62(8): 2866-2868.

Hassan, M.G.; Al-Hayali, N.S. and Sultan, I.A. (2002): Incidence of protozoa pathogens in some meat products. Raf. J. Sci. 14(4): 16-21.

Katz, M.H. (2006): Bivariate statistics. In: Katz (editor), Study design and statistical analysis. Cambridge, University City Press, New York, USA.

Kligour, R. and Dalton, C. (1984): Lives tock behaviour: A practical guide. $1^{\text {st }}$ ed. Granada publisher. London. PP.85-97.

Laberge, I.; Griffiths, M.W. and Griffiths, M.W. (1996): Review article prevalence detection and control of Cryptosporidium parvum in food. Int. J. Food Microbiol., 32: 1-26.

Mann, E.D.; Sekla, L.H.; Nayer, G.P.S. (1986): Infeaction with of Cryptosporidium spp. In human and cattle in Manitoba. Can. J. Vet. Res. 50.174-178.

Mohammed, H.O.; Wade, S.E; Schaaf, S. (1999): Risk factors associated with Cryptosporidium parvum infection in dairy cattle in southeastern. NeW York State. Vet. Parastioal. $83(1-13)$.

Mosa, A.I. (2016): Occurrence of Cryptosporidium species and Toxoplasma gondii as protozoan parasites in raw milk. Ph.D. Thesis, Fac. of Vet. M. Assiut, Egypt.

Naciri, M.; Lefay, M.P.; Mancassola, R.; Poirier, P. and Chermette, R. (1999): Role of
Cryptosporidium parvum as a pathogen in neonatal diarrhea complex in sucking and dairy calves in France. Vet. Parasitol.; 85(4): 245-257.

Norhamizah, A.H.; Julaida, S.; Slamah, B.; Saudah, S. and Rasidah, A.L. (2011): Cryptosporidiosis in A commercial dairy cattle farm in Malaysia. Malaysian Journal of Veterinary Research. (2)2: 33-39.

Rasheed, R.N. (1997): Cryptosporidiosis in Iraqi goat kids. The veterinarian, 6(1): 5-8.

Smith, H.V.; Robertson, L.J.; Ongerth, J.E. (1995): Cryptosporidiosis and giardiasis, the impact of waterborne transmission. Journal of water supply: Research and Technology - AQUA 44, 258-274.

Smith, J.L. (1993): Cryptosporidium and Giardia as agents of food borne disease. J. Food. Prot. 56, 451-461.

Smith, H.V. and Nichols, R.A.B. (2009): Cryptosporidium: Detection in water and Food. Experimental Parasitology XXX(1-19) .

Taylor, M.A.; Coop, R.L. and Wall, R.L. (2007): Veterinary Parasitology $.3^{\text {rd }}$ edition. Black wall publishing Ames, Iowa, USA: 180-181.

Urquhart, G.M.; Armour, J.; Dun can, J.L.; Dunn, A.M. and Jennings, F.W. (2003): Veterinary Parasitology, $2^{\text {nd }}$, Black well publishing company, Oxford, PP: 72-73, 233.

Xiao, L.; Fayer, R.; Ryan, U. and Upton, S.J. (2004): Cryptosporidium oxonomy: recent advance and Implications for public health. Clin. Microbiol., 17(1): 72-97.

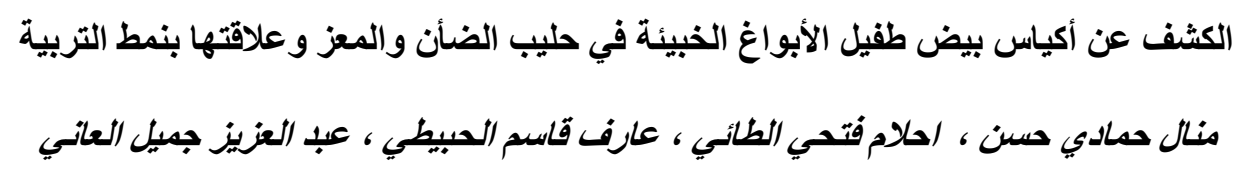

E-mail: manalhimmadi69@yahoo.com Assiut University web-site: www.aun.edu.eg

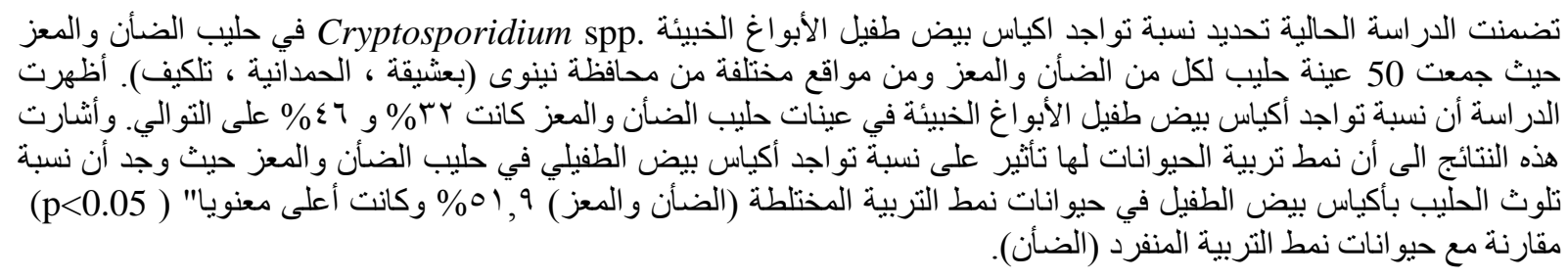

